\title{
Pre- and post-settlement events in benthic community dynamics
}

\section{Les événements de pré- et post-installation larvaire dans la dynamique des communautés benthiques}

\author{
Simonetta Fraschetti *, Adriana Giangrande, Antonio Terlizzi, Ferdinando Boero \\ Laboratorio di Zoologia e Biologia Marina, Dipartimento di Scienze e Tecnologie Biologiche ed Ambientali, Università di Lecce, CoNISMa, \\ 73100 Lecce, Italy
}

Received 29 January 2002; received in revised form 11 April 2002; accepted 17 June 2002

\begin{abstract}
In all marine benthic environments, organism replacement depends on recruitment limitation, i.e. the impact of both pre- and post-settlement events on the success of recruitment. The relative contribution of pre- versus post-settlement processes in shaping adult populations has been extensively studied. Most analyses concluded that recruitment limitation is a strong determinant of adults' density. The magnitude of its limitation depends on context, varies with species, and can be strongly modified by all the events preceding and following recruitment itself. A comparison of the outcome of recruitment limitation on hard- and soft-bottom communities has often been neglected. The rules governing these two environments, in both the inter- and the subtidal, might be inferred only by comparing and possibly integrating soft- and hard-bottom ecologies. The highly variable situation that larvae face in the water column is followed by the variability linked to local features, influencing, in its turn, larval settlement and juvenile survival (post-settlement period). A better knowledge of these processes will be possible only by focusing on their relative importance in the two environments and with research on the brief but significant time of larval settlement.
\end{abstract}

(C) 2002 Ifremer/CNRS/IRD/Éditions scientifiques et médicales Elsevier SAS. All rights reserved.

\section{Résumé}

Le remplacement des organismes dans l'environnement benthique dépend de la limitation du recrutement, succession des événements précédant ou suivant immédiatement la sédimentation larvaire. La contribution relative des processus de pré- et de post-installation dans la structuration des populations adultes a été largement étudiée. La majeure partie des analyses conclut que le recrutement est un facteur clé pour assurer le renouvellement et le maintien des adultes. Une comparaison de la limitation du recrutement sur les communautés de substrats durs et meubles a été rarement effectuée. Les processus affectant ces deux environnements, aussi bien dans la zone intertidale que subtidale, peuvent être déduites seulement en comparant (et éventuellement en intégrant) l'écologie des fonds durs et meubles. La situation très variable que les larves rencontrent dans la colonne d'eau (période de pré-installation) est dûe à la variabilité des caractéristiques locales. Celles-ci influencent, à leur tour, l'installation des larves et la survie des juvéniles (période de post-installation). Une meilleure connaissance de ces processus sera possible seulement après l'identification de leur importance relative dans les deux environnements et si l'étude de la période d'installation des larves, brève mais significatif, sont étudiés.

(C) 2002 Ifremer/CNRS/IRD/Éditions scientifiques et médicales Elsevier SAS. Tous droits réservés.

Keywords: Recruitment limitation; Pre- and post-settlement events; Benthos; Plankton; Life-cycles

Mots clés: Limitation du recrutement; Evénements pré- et post installation; Benthos; Plancton; Cycles vitaux

\footnotetext{
* Corresponding author.

E-mail address: sfrasca@ilenic.unile.it (S. Fraschetti).
} 


\section{Introduction}

The influence of larval supply and recruitment on the structure of adult populations of marine organisms has been recognized for at least 90 years. Benthic marine invertebrates release sexual propagules (e.g. zygotes, larvae, or juveniles) that either settle near the parents or develop in open waters as planktonic larvae. These are dispersed by currents to destinations that can be more or less favorable for settlement and metamorphosis. The success of each developmental step, occurring in different habitats, affects the dynamics, demography and genetic structure of populations, and the composition of communities. Thorson (1950) argued that variation in larval settlement leads to variation in adult population size, assuming recruitment limitation. Later, however, theories of density-dependent population regulation prevailed over life-cycle-based theories, at least in benthic ecology. Communities, thus, were considered as closed units at equilibrium, regulated by competition and predation (Paine, 1974; Diamond, 1978). In that period, the development of alternative models to the land-based facilitation model, namely the tolerance and inhibition models, was benthic-based (Connell and Slatyer, 1977). In the facilitation model, propagule availability is constant and the outcome of succession is linked exclusively to interactions between benthic adults. Both the tolerance and the inhibition models predict that propagule availability determines the outcome of successions with interactions taking place after settlement. In spite of their implied importance, pre-settlement events were excluded from the models.

Lottery models, explaining diversity with the differential success of the larval phases of the species making up communities were exceptions to this trend. The equal changes hypothesis (Sale, 1977) explained species coexistence by assuming that empty space could be filled at random by recruits from a large pool of potential colonists. The storage effect (Chesson and Warner, 1981) predicted that recruitment fluctuations promote species coexistence in communities of long-lived organisms.

Interest in non-equilibrium processes led to re-appreciate the role of recruitment in determining population structure (Underwood and Fairweather, 1989).

In this framework, the idea that populations are either open (i.e. requiring propagule inputs from other populations, recruitment to a site being independent from the resident community) or closed (i.e. producing their own propagule supply) was developed (Gaines and Roughgarden, 1985; Underwood and Fairweather, 1989; Gaines and Lafferty, 1995). In closed systems, propagules are dispersed within the geographical boundaries of local populations, and therefore, it is possible to predict subsequent population demographics from local offspring production. In open systems, propagules may be dispersed within and among populations, obscuring any relationship between reproductive output and propagule abundance on a local scale (Booth and Brosnan, 1995). Population persistence at unfavorable sites can be maintained by continued immigration from more productive 'source' areas (Dias, 1996). According to supply-side ecology (Lewin, 1986), any description of population dynamics of organisms with complex life cycles requires data on larval supply, local population size being linked to propagule inputs. Therefore, supply-side ecology proposed recruitment models, especially for marine intertidal species, based on the 'open system' assumption (Gaines and Roughgarden, 1985). Nevertheless, the openness of a population is still difficult to demonstrate (Booth and Brosnan, 1995), also because the choice of models is scale-dependent (Roughgarden et al., 1988; Hughes et al., 1999).

Some authors (e.g. Rodriguez et al., 1993) considered the distinction between open and closed systems as irrelevant. At some scale, in fact, most ecological systems are open (Menge, 2000), becoming closed at larger spatial scales. Recruitment in marine populations can be modeled by metapopulation approaches, but migration among populations, presumably high for most marine organisms, makes the metapopulation approach less applicable in marine environments than on land (Caley et al., 1996; Hanski and Simberloff, 1997).

There is growing evidence that both pre- and postsettlement events influence the demography of many benthic species with pelagic larvae (Morgan, 2001). Marine ecologists are currently debating whether marine benthic populations and communities are limited by either planktonic or benthic recruitment-related processes (Hughes, 1990; Olafsson et al., 1994; Caley et al., 1996; Hunt and Scheibling, 1997) and many questions remain unanswered yet (Booth and Brosnan, 1995; Menge, 2000). In spite of a great interest in the relative importance of recruitment limitation on both hard- and soft-bottom assemblages, few attempts have been made to find general rules for the two environments. As argued by Hall et al. (1992), much of the inspiration for studies in soft-bottom habitats comes from research on rocky shores. Crossreferencing between the two, however, has often been neglected (Lake, 1990; Glémarec and Guillou, 1996; Hunt and Scheibling, 1997; Morgan, 2001). This paper reviews the relative importance of pre- versus post-settlement events in soft- and hard-bottom communities, comparing (and possibly integrating) the general rules governing these two environments.

\section{Primary versus secondary recruitment limitation}

Recruitment limitation can be defined as the sum of preand post-settlement events. Primary recruitment limitation (i.e. pre-settlement events) depends on water column processes and involves planktonic larval mortality, affecting larval supply. According to this definition it can be considered as identical with supply-side ecology (Palmer et al., 1996). Secondary recruitment limitation (i.e. post- 
Table 1

Settlement, recruitment and recruitment limitation: some definitions

Pre-settlement events Settlement

Post-settlement events

Recruitment

Recruitment limitation

Post-recruitment events

Temporary meiofauna
Include production, survival and dispersal of larvae in the water column; probably they comprise also adult-larval interactions. The process of becoming associated with the substrate; influenced by substrate availability and selection; contact with substrate reversible or irreversible; larval exploratory behaviour, orientation, and metamorphosis may occur before, during or after contact with substrate.

Interactions between established adults and just-settled individuals, involving release of chemical cues, interference by bioturbation, disturbance and food limitation, local flow patterns, predation, intra- and interspecific competition for space.

Settlement is a biological phenomenon, but recruitment is not; in most cases it is observer-defined and requires an operational definition such as 'the entry into the benthic population of individuals that have survived to a specified size after their settlement, without already being adult' (Booth and Brosnan, 1995). Definitions will continue to differ from species to species, being related to longevity, growth rate and by the time frame selected by the investigators (Hunt and Scheibling, 1997).

Influence of both pre- and post-settlement events (Fig. 1) keeping recruitment at a rate insufficient to maintain a given population size or, according to Sutherland (1990), to fill all available space. This definition may not fit with soft-sediment, where food limitation may be more limiting than space (Peterson, 1991).

Recruit exposure to physical and hydrodynamic disturbance, food limitation, interactions between recruits and established adults, such as interference by bioturbation, predation, intra- and interspecific competition for space. The difficulty of defining recruitment makes separation between post-settlement and post-recruitment events operationally difficult; authors often ascribe to post-settlement events any factor affecting mortality after settlement (Olafsson et al., 1994).

Settled macrofauna juveniles with the same size $(<500 \mu \mathrm{m})$ as the permanent meiofauna. On rocky bottoms, newly settled sessile organisms are defined as juveniles, those of vagile organisms are mostly overlooked. On soft-bottoms, predation by permanent meiofauna has been suggested to exert an important role in controlling newly settled individuals (Watzin, 1983; Zobrist and Coull, 1992). Planktonic larvae are considered as the most vulnerable stage in the life-cycle of marine invertebrates (90\% of larval mortality, Thorson, 1950) but recent evidence (Ellien et al., 2000) suggests that post-settlement mortality can be higher than pre-settlement mortality. settlement events) is due to benthic settler mortality, affecting early post-larval supply, or realized recruitment (Hunt and Scheibling, 1997). Since in the literature the terminology used to define pre- and post-settlement events has been very often used in different ways in similar contexts, a synthesis of definitions is shown in Table 1.

Recruitment limitation was particularly studied for rocky benthos and reef fishes, where adult abundances can be limited by the rate of propagule arrival at a site (presettlement events) rather than by post-settlement events (Chesson, 1998).

Pre-settlement events operate at much larger scales than post-settlement ones. Large-scale studies, thus, emphasize a plankton-based primary limitation of benthic communities, whereas small-scale studies stress a benthos-based secondary limitation (Butman, 1987; Caley et al., 1996). Stoner (1990) suggested that pre-settlement events could influence recruits' distribution, while post-settlement mortality affects juvenile density.

Most species presumably suffer high pre-settlement mortality (Ellien et al., 2000), but the magnitude of early post-settlement mortality is mostly unknown (Gosselin and Qian, 1997). These two kinds of mortality probably have different weight in soft- and hard-substrate communities, depending on differences in both life-cycle features, and in controlling environmental factors (Table 2). Pre-settlement events were stressed particularly for intertidal hard substrates (Underwood and Fairweather, 1989). In contrast, just a few studies searched for a possible primary recruitment limitation in soft substrates (Thrush et al., 1996), where much attention was focused on post-settlement events (Olafsson et al., 1994; Norkko et al., 2001).

\section{Technical problems}

The reason for the unfortunate gaps among larval and benthic studies is possibly that larvae and juveniles are small, typically transform rapidly, and are overlooked for technical reasons during ecological studies. The same problem arose in connecting plankton dynamics to the storage of plankters' resting stages in the benthos (Boero et al., 1996; Marcus and Boero, 1998). Studies on larval supply to intertidal hardsubstrate assemblages started to fill the gap: research on barnacle larval dynamics gave the opportunity to test specific hypotheses concerning larval supply (Gaines and Bertness, 1992). More recently, a growing field of interest is concerned with the study of the role of hydrodynamic processes on larval transport (Bertness et al., 1996; Ellien et al., 2000). Because of poor swimming abilities (the vast majority of invertebrate larvae swim at a speed less than $1 \mathrm{~mm} \mathrm{~s}^{-1}$, Chia et al., 1984), larval dispersal depends mainly on mesoscale spatial hydrodynamic features (tidal residual currents, winddriven currents front and gyres). But larval transport behavior is not yet well known for rocky shore species, except for estuarine barnacles. As far as soft sediment is concerned, although passive mechanisms alone sometimes can be sufficient to retain weakly swimming larvae in estuary, decades of laboratory and field studies have shown that behavior facilitates retention. However, working with larvae in natural habitats is difficult and often requires innovative approaches and technologies. Larval identification is often difficult due to the uniform morphology of many larvae and their mortality is difficult to estimate, being often indistinguishable from juvenile mortality (Hines, 1986). Settlement has been widely studied by both behaviorists and embryologists, but settlers' size and behavior make field documentation of settlement 


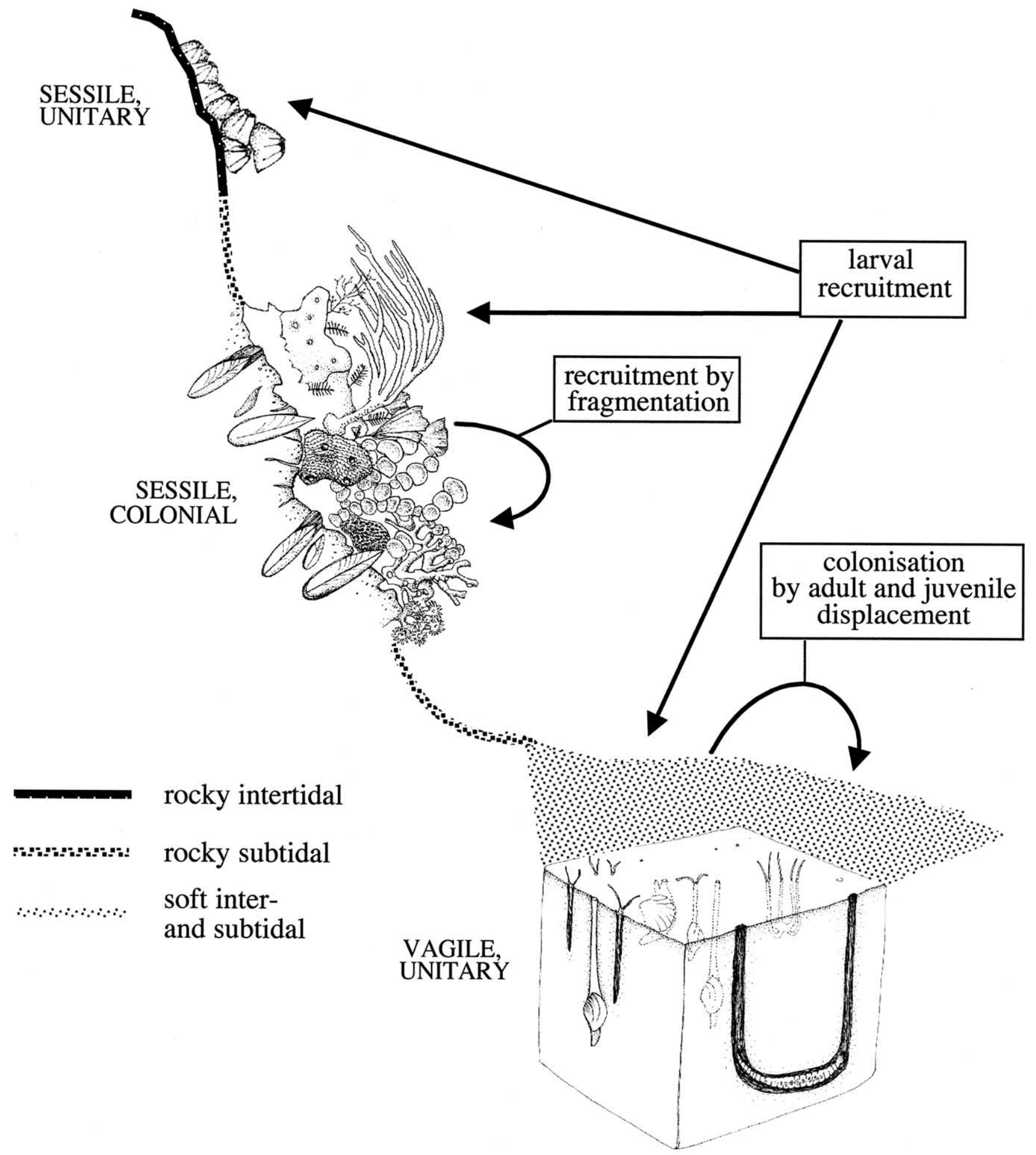

Fig. 1. Main life styles and consequent recruitment and recolonization modes in marine benthos, with a scheme of in- and epifaunal distribution on rocky and soft bottoms (see also Woodin and Jackson, 1979). Hard substrates are used as bidimensional surfaces by primary settlers, but communities can be multistratified by epibiosis. Besides few endolithic species, most organisms grow into the water column and use a tridimensional feeding space. On soft bottoms, organisms use the substrate in a tridimensional way, mainly growing into it, but, with the exception of sediment engulfers, their feeding organs contact the water column through the sediment surface, so having a bidimensional feeding space.

events uncommon (Hurlbut, 1991; Rodriguez et al., 1993). Thus, settlement success is often inferred from recruitment data measured after days or even weeks from actual settlement (Davis, 1987; Richmond and Seed, 1991). Conse- quently, links among life-history phases are not easily detected, and just a few studies report on quantities of larvae, juveniles and adults (Feller et al., 1992; Eggleston and Armstrong, 1995). 
Table 2

Main features of hard- and soft-bottom communities. As an exception, in intertidal hard-bottoms the prevailing life styles are sessile, gregarious, individual (e.g. mussels and barnacles)

\begin{tabular}{lll}
\hline Feature & Hard bottoms & Soft bottoms \\
\hline Distribution & Patchy & Patchy \\
Substrate inclination & All possible states & Mainly horizontal \\
Sources of natural stress & Sedimentation, low nutrient levels, waves & Substrate instability \\
Competition for space & High, direct and indirect & Low, mostly indirect \\
Competition for food & High, direct and indirect & Low \\
Prevailing life styles & Sessile, gregarious, clonal, perennial & Individual, vagile \\
Dispersal by & Asexual fragments, rafting adults, larvae & Adults, larvae \\
Post-settlement displacement & Generally not important & Important \\
Overcrowding, overgrowth & Important & Negligible \\
Larvae/adult negative interactions & Important at high settlement rates & Important at high density \\
Predation on recruits & Mainly from suspensivores and grazers & Mainly from suspensivores, deposit feeders, and permanent \\
& & meiofauna \\
Adult/adult negative interactions & Important at high recruitment rates (space is limiting) & Less important \\
Dominant trophic groups & Suspension-feeders and grazers & Detritus-, deposit- and suspension-feeders \\
\hline
\end{tabular}

\section{Soft versus hard substrates}

The soft subtidal macrofauna is dominated by small, individual, mobile and cryptic organisms (burrowing annelids, molluscs, crustaceans, and echinoderms). On hard subtidal substrates, excluding the very small vagile shortlived species living within algae, usually neglected in this environment (Lake, 1990), long-lived unitary organisms and sessile colonial or gregarious forms are dominant (algae, sponges, cnidarians, bryozoans, tunicates). As remarked by Jackson (1977) the situation is radically different in the rocky intertidal, dominated by algae and sessile solitary molluscs and crustaceans. The study of this exception, paradoxically, led to many rules in marine ecology. The rocky intertidal, in fact, is the most widely studied marine environment, especially from an experimental point of view. This choice is not due to particular reasons leading to consider intertidal ones as the paradigm of marine communities. Convenience due to easy access is probably the main reason for this burst of studies.

In spite of the differences between hard- and soft-bottom organisms, however, their larvae are all individuals and have to settle after a planktonic period.

Physical differences between hard and soft substrates are dramatic: rocks are two-dimensional and, besides a few endolithic species, organisms attach to their surface, whereas sediments are three-dimensional and organisms can escape flow forces and other surface phenomena by burrowing (Peterson, 1979; Butman, 1987). However, burrowing soft-substrate organisms interact with the water column from a two-dimensional surface, whereas hard-substrate organisms can have a three-dimensional contact with the water column (Fig. 1).

Rocky-substrate communities are characterized by patchy distributions. The gaps in continuity among hard-substrate habitats can be bridged by massive organisms such as mollusc shells, forming islands that hard-bottom species use to survive on and go across vast soft bottoms. At temperate latitudes many sessile organisms seem to disappear during unfavorable periods, but remain in quiescent structures as resting stages, being, therefore, constantly present (Coma et al., 2000). Other than by larvae and adult rafting, clonal hard-bottom organisms, dominant in the subtidal, can disperse by fragments and specialized asexual propagules (Highsmith, 1985), whereas many intertidal species are non-modular and disperse mainly by larvae (Jackson, 1977). Although the evidence for most of these causes of mortality is sparse and often equivocal, the planktonic period remains a period of great mortality for many species. Therefore, this difference in life history patterns results in a much greater impact of pre-settlement events in intertidal hard-bottom habitats than in subtidal ones.

Soft substrates are more widespread than hard ones. Their communities only apparently show a less patchy distribution than hard-bottom ones (Kendall and Widdicombe, 1999). Conversely, especially in shallow and intertidal sediments, they are typically characterized by nonrandom (or patchy) patterns in the spatial arrangement of individuals and assemblages (Hall et al., 1992). Most of the animals are characterized by short life cycles and by high intra-annual density variations that drastically affect the potential for recolonization on a predictable seasonal basis. Adult recruitment is known to be very important in lateral recolonization strategies, performed by juveniles and adults moving through the sediments rather than by larvae (Frid, 1989). Juvenile and adult dispersal can occur through the sediment as well as the water column by drifting specimens (Wilson, 1994). This results in highly patchy distributions of burrowing deposit feeders, burrowing suspension feeders, and tube builders of various trophic types (Morgan, 2001). Although post-settlement displacement is considered negligible for most unitary sessile species living on hard substrates, it can be important in local population dynamics of highly mobile species, often obscuring the settler-recruit relationship (Pile et al., 1996).

Competition for space is strong on hard substrates: a winning tendency is, in fact, to maintain the occupied position. Competitive interactions are difficult to demon- 
strate in soft-bottom habitats, where smothering and undercutting mechanisms are not relevant. Thus, competition for space seems weaker than in hard-bottom habitats and indirect competition or sediment-mediated interactions predominate (Ambrose, 1984).

Negative post-settlement interactions can be important in both environments. On hard substrates, overcrowding and overgrowth, less important in soft ones, can result in density-dependent early post-settlement mortality (Buss, 1990; Rinkevich et al., 1998). The inhibition model of community development may be more applicable than in soft bottoms (Standing, 1976), where facilitation often takes place (Connell and Slatyer, 1977; Gallagher et al., 1983). The tolerance succession model is most applicable for soft-sediment communities, and life-history features mostly determine the successional sequence of species (Lake, 1990). The model explains fluctuations in species abundances and community composition by changes in food availability. However, opportunistic species have rarely been demonstrated to be directly outcompeted by the species that enter later in the succession. Nevertheless, strong negative interactions among larvae, juveniles and adults have been hypothesized as the main factors structuring dense infaunal assemblages (Ambrose, 1984).

Finally, the impact of meiofauna, rather high in interstitial habitats (Zobrist and Coull, 1992), is possibly a postsettlement factor with different impact in the two environments, being largely assessed for soft-bottom communities (Watzin, 1983), but almost unknown in rocky bottoms (Coull and Wells, 1982).

The above features show substantial differences in hardversus soft-substrate communities influencing recruitment patterns and processes. It is worthwhile, at this stage, to outline the main recruitment patterns recognized as typical for the species inhabiting these contrasting environments.

\section{Hard bottoms}

Supply-side interpretations of community dynamics have been applied to intertidal rocky-bottom communities with such a success that the 'open-system hypothesis' rapidly has become a dogma (Sale, 1990). The importance of the initial settlement patterns on zonation of adult barnacles has been well documented in the intertidal (Gaines and Roughgarden, 1985; Minchinton and Scheibling, 1991; Jenkins et al., 2000). Especially in sessile organisms, in fact, it is the larva to choose the conditions experienced by the adult for the rest of its life (Anderson and Underwood, 1994). Studies of recruitment processes in subtidal hard substrates are less common. With the exception of a few studies on barnacles, bryozoans, ascidians and polychaetes (Hughes, 1990; Hurlbut, 1991; McKinney and McKinney, 1993), data on the events leading to recruitment of important taxa are still scant (Hunt and Scheibling, 1997; Lasker et al., 1998).
At local scales, the recruitment of subtidal benthic species with pelagic larvae should be considered in terms of regional differences in both pre- and post-settlement processes (Stoner et al., 1996). Locally variable larval supply can dramatically impact the spatial distribution and abundance of settlers (Gaines and Bertness, 1992). At two subtidal sites in southern Australia, recruitment varied considerably at all spatial and temporal scales, with little synchrony in recruitment peaks between sites and between years (Hughes et al., 1999). Major peaks in recruitment for one species at one site are not necessarily matched by recruitment peaks of the same species at another site. This provides little support for the concept of generally "good" or "bad" years for a coastal region as a whole (Keough, 1983). Variation in recruitment does not match variation in the abundance of adults, indicating that probably other demographic processes (e.g. abundance of competent larvae in the vicinity of a suitable substratum, hydrodynamic conditions close to the substratum and post-settlement mortality) also vary between locations (Archambault and Bourget, 1999).

It has been traditionally assumed, often implicitly, that recruits are in plentiful supply and that local population size is determined solely by post-recruitment interactions and mortality from disturbances. In the intertidal, a positive relationship between the abundances of recruits and settlers has been found in most studies of sessile species, mainly barnacles (Hunt and Scheibling, 1997). In the subtidal, the space available at the time of settlement, along with competition or predation, determines organisms' abundance. This, for instance, was shown for bryozoans and ascidians (Osman and Whitlatch, 1995). In several cases, postsettlement mortality may falsify predictions on recruitment patterns based on settlement alone (Hurlbut, 1991), neglecting the processes operating immediately after settlement. Therefore, it is still under debate whether post-settlement mortality can obscure the relationship between recruits and settlers abundance, especially when early post-settlement mortality is density independent.

For mobile species, studies on the relationship between recruit and settler abundance have produced variable results. In these taxa, post-settlement movement can relieve overcrowding due to high settlement intensity (Whale and Incze, 1997).

If larval settlement is low, both empirical (Connell, 1985; Sutherland, 1990) and theoretical (Roughgarden et al., 1985) studies indicate that only density-independent mortality is likely to occur, and populations are thus limited by larval supply. That is, the relative importance of recruitment versus post-recruitment factors varies inversely with increasing density of recruits (Menge, 2000). If settlement is intense, mortality may be density-dependent and the predominant features of population structure are the result of post-settlement events (Connell, 1985; Gaines and Roughgarden, 1985; Roughgarden et al., 1985; Roegner, 1991). When mortality of newly settled larvae is density indepen- 
dent, the age structure of populations directly reflects previous settlement events (Holm, 1990).

The magnitude of the relationship between recruitment and adult density is strongly dependent on the environmental context, varies with species, and can be modified by post-recruitment processes (Menge, 2000). Moreover, postrecruitment factors can be important in determining adult density even when density of recruits is low.

High longevity, with storage of cohorts in the population, also makes it difficult to detect the role of recruitment (Warner and Chesson, 1985; Hughes, 1990). When storage is high, adults accumulate during multiple recruitment events, and recent pulses of recruitment have only minor effects on the total number of individuals, compared to shorter-lived populations.

Recruitment limitation is a concept stemming from population studies, but it has received such emphasis on rocky shores to be incorporated within community models (Menge and Sutherland, 1987). However, the relationship between recruitment and adult abundances has rarely been expanded to whole communities (Menge and Farrel, 1989), and a correlation between high recruitment rates and adult densities has rarely been found (Menge, 1991). Moreover, this correlation becomes increasingly weak with the increasing influence of post-recruitment mortality due to predation and interspecific competition (Sutherland and Ortega, 1986).

\section{Soft bottoms}

Notwithstanding supply-side ecology reflects Thorson's ideas for soft-bottom communities, studies of soft bottoms are probably less conceptual than those of rocky bottoms (Constable, 1999). In fact, very few studies have tried to produce general conclusions about relationships between larval, juvenile and adult abundances of soft-bottom invertebrates (Ellien et al., 2000; Thiébaut et al., 1998). This is possibly due also to technical problems, including difficulties in conducting in situ measurements and experiments on unconsolidated sediments. Moreover, as pointed out also for hard substrates (Stoner et al., 1996), an understanding of recruitment processes requires consideration of what determines the abundance of competent larvae near the bottom, rather than of those in the water column.

The importance of adult-larva (pre- and post-settlement) and adult-juvenile (post-recruitment) interactions in structuring communities (Ambrose, 1984; Thrush et al., 1996), thus influencing the density of adult infauna, was suggested also for soft-bottom environments. Despite the consolidate evidence that soft-bottom communities are characterized by wide intra- and interannual fluctuations, the importance of larval supply in dictating population and community structure in soft sediments has rarely been considered (Olafsson et al., 1994). In just a few cases, a constant adult density linked to fluctuating recruitment was demonstrated to be the result of storage of different cohorts rather than of density- dependent mortality (Noda and Nakao, 1996). In the Bay of Seine (English Channel), the observed temporal stability in an Abra alba-Pectinaria koreni community through four winter surveys has been considered to be also generated by processes of larval retention near parental population (Thiébaut et al., 1997).

As stressed for hard bottoms, a tendency is to consider larval supply as not limiting on soft bottoms (Peterson and Summerson, 1992) and probably not a major determinant of patterns of species distribution and abundance in sedimentary habitats. However, even though Olafsson et al. (1994) concluded that pre-settlement processes were not important for shaping soft-bottom assemblages, Young et al. (1998) and Thiébaut et al. (1998), for instance, suggested that wind-induced larval transport is a major contributor to interannual recruitment variation of the bivalve Cerastoderma edule and the polychaete P. koreni.

In soft bottoms, the relationship between the abundances of benthic adult and those of planktonic larvae has not been demonstrated for species with great year-to-year variation. In this case, post-settlement processes are considered good candidates to explain the observed trends (Olafsson et al., 1994). For instance, a high settlement of the bivalve Mya arenaria after an extremely severe winter, which killed most adults, did not coincide with high abundances of planktonic larvae. Hence, the strong year class following the mass mortality event was probably not due to higher settler availability but to high settler survival due to absence of inhibiting adults (Powell et al., 1984). The boundaries observed between discrete, often age-class dominated infaunal assemblages are due to interactions between established individuals and settling larvae (Crowe et al., 1987). In dense infaunal assemblages, adult abundances represent a sort of filter (i.e. trophic group amensalism), inhibiting the transition of larvae from the plankton to the benthos through sediment change, filtration of larvae, ingestion or deposit of pseudofeces, defecation, spatial limitation by tube density. All these mechanisms can be responsible for the maintenance of sharp boundaries in large dense assemblages (Woodin, 1976), and contribute to keep infaunal density below the carrying capacity, avoiding further adult-adult negative interactions (Ambrose, 1984). Thus, similar to hard bottoms, a central question concerns the importance of density-dependent processes (David et al., 1997). Inhibition has been predicted to be the most important factor in structuring soft-sediment communities when densities of adults were high, much as eventually was demonstrated for rocky intertidal communities.

Olafsson et al. (1994) noted that, for soft-sediment invertebrates, evidence supports the hypothesis that adult deposit- and suspension-feeders inhibit recruitment and that, to a lesser extent, juvenile mortality and growth are reduced through competition for food. However, while the densitydependent inhibition of recruitment by adult deposit feeders has frequently been documented, similar effects of adult suspension feeders seem less consistent (André and Rosen- 
berg, 1991; Thrush et al., 1996). The diversity of animal biology makes generalizations based on functional aggregations problematic; the features of individual species are to be understood to pose more reasonable and testable hypothesis (Weinberg, 1984).

Density-independent processes such as post-settlement predation, as found in the bivalve Cerastoderma glaucum (McArthur, 1998), and hydrodynamic disturbance were also found to have significant effects. The relative extent of density-dependent versus density-independent recruitment regulation, therefore, remains to be determined (David et al., 1997).

Besides the adult-larval correlation, for many species it is not even possible to identify a direct correlation between settlers and recruits. Abundances, in fact, decrease rapidly after settlement peaks and tend to level off at densities unrelated to the temporary abundance of settlers (Olafsson et al., 1994). Newly settled macrofauna start their benthic life as temporary meiofauna and it is possible to find a stronger correlation between the abundances of planktonic larvae and meiofaunal settlers than between meiofaunal and macrofaunal abundances. This suggests important mortalities in the meio-macrofaunal transition (Feller et al., 1992; Gosselin and Qian, 1997). Temporary and permanent meiofauna strongly interact: meiofaunal turbellarians, for instance, predate on just settled individuals, maintaining low macrofaunal densities (bottleneck hypothesis: Zobrist and Coull, 1992). A post-larval bottleneck was found also in deep-sea benthos where nutritional constraints and competition with larger deposit-feeding adult stages, and vulnerability to grazing, might cause differences between the dynamics of post-larval and adult pools (Gage, 1994).

\section{Conclusion}

Predictions on the effect of the timing and magnitude of recruitment on marine benthic communities are still rather vague (Benedetti-Cecchi, 2000). The few available longterm studies on recruitment variability of soft-bottom benthic taxa show that benthic-pelagic coupling is evident only at the broad levels of abundances or biomass (Austen et al., 1991), or that there is no coupling between planktonic and benthic populations. However, the link between larval abundance in the plankton and the just settled temporary meiofauna is more evident (Feller et al., 1992). For hardbottom communities, a correspondence between larval and adult abundances has only been detected in few intertidal species. A correlation between high recruitment rates and adult densities has rarely been found at community level, becoming increasingly weak with the increasing influence of post-recruitment factors (Menge, 1991).

At small scales, recruitment is highly variable in both hard and soft bottoms. Most species have predictable peaks of recruitment at particular times of the year, but peak size can be predicted only in a probabilistic fashion, based on long-term series of recruitment patterns. Moreover, only when juvenile growth is fast, seasonal changes in density and biomass of adults can be related to densities at settlement. If juveniles grow slowly, in fact, the densities of benthic juveniles (temporary meiofauna) are already significantly reduced when they pass to the macrofauna. Densities of benthic recruits, therefore, have only a slight influence on the dynamics of adults. Thus, it is not surprising that many existing empirical demonstrations of recruitment limitation are based on relatively short-lived taxa, whose populations comprise only few cohorts (Caley et al., 1996).

On both rocky and soft bottoms, the transition from pelagic to benthic environments prior to attaining macrofaunal size includes potentially important but poorly known events affecting both larval and juvenile survival. On soft bottoms, recruits have to pass through predation by permanent meiofauna, suspensivores and deposit feeders, before 'escaping in size' to the macrofauna. The impact of the permanent meiofauna on recruits is almost unstudied on hard bottoms. In contrast recruits are much sensitive to macrofaunal suspensivores and grazers before they can 'escape in size' into the macrofauna (Osman et al., 1992; Danovaro and Fraschetti, 2002).

Without sampling the transition phase, benthic ecologists have a diminished understanding of the relationships between larval planktonic and adult benthic communities. The correlation between larval quality and quantity in the water column and adult quantity and quality on the bottom, in fact, cannot be detected a posteriori (Feller et al., 1992).

Supply-side ecology predicts that individuals die and are replaced by recruitment, propagule availability and success being the ultimate causes for community persistence. This should still be considered an essential issue but it must be stressed that such processes take place in a much-varied array of patterns. Most field studies of fine-scale temporal variation in settlement and mortality have examined individual species, such as barnacles. Complex communities, however, harbor species with contrasting life history and dispersal strategies. Both in hard and soft bottoms, and within the same community, populations can be open or closed depending on specific life-cycle strategies and on the considered spatial scale. Species with long-lived larvae tend to be more evenly distributed than species with short-lived larvae (Bingham, 1992). Species with short-lived larvae typically have patchy distribution, being strongly affected by the location of source populations. The generality of this assumption is falsified by the distribution of hydroids and medusae in the Mediterranean, where species' distributions are not affected by the presence or absence of a medusa in the life-cycle (Boero and Bouillon, 1993). Thus, the assessment of settlement and mortality patterns for a single species may not represent all components of a community, and important interactions among species may be missed. At the community level, the persistent tendency to draw 'general' rules from studies on 'particular' communities (i.e. intertidal ones, from mud flats to rocky shores) makes Jackson's 
(1977) warning on the limits of intertidal studies still valid. Supply-side ecology results from generalizations of studies on a few sessile, intertidal and unitary species (Connell et al., 1997). These species are highly dependent on larval import from the water column, so those large open patches are primarily recolonized by recruits from the plankton, making pre-settlement events particularly important.

In subtidal hard-bottom communities, dominated by sessile modular organisms, however, such recruitment patterns might be of less general application. The same applies to subtidal soft bottoms (Frid, 1989), albeit for different reasons. In the subtidal, in fact, hard bottoms can be recolonized by fragmentation of adult sessile organisms, whereas on soft bottoms recolonization can also be due, besides larvae, to displacement of adult meio- and macrofauna (Fig. 1). Therefore, post-settlement events are particularly relevant both on hard- and soft-bottom subtidal environments. Obviously, post-settlement processes can only act on settled individuals, but predicting population abundance and community structure requires an understanding of the relative intensity of these various processes.

Biodiversity has a bearing on the ability of a community to cope with changing environmental pressures by changing dominance of species differentially adapted to specific contingencies. This often leads to difficulties in using modeling techniques based on species living in particular environments. The vast array of life styles of marine benthic organisms calls for a more efficient integration of sophisticated modeling with traditional 'natural-history'. Huismann and Weissing (2001), finally, demonstrated, with numerical simulations, the 'fundamental unpredictability' of the outcome of community functioning even while considering just competition. Ecologists are starting to distinguish between reducible and irreducible ignorance (Faber and Proops, 1993). This should focus research towards an understanding of community organization and functioning based on bioecological grounds (Highsmith, 1985; Boero, 1996; Giangrande et al., 1994).

\section{Acknowledgements}

F. Micheli and R. Danovaro critically reviewed an earlier version of the manuscript. M. Soullard and G. Cancemi helped with abstract translation. Thanks are also due to the referees, whose suggestions greatly improved the manuscript. The Province of Lecce, MURST (Cofin project), C.N.R. (PRISMER 2 project), and the INTERREG II Italy-Greece and Italy-Albania projects, provided financial support.

\section{References}

Ambrose Jr, W.G., 1984. Influence of residents on the development of a marine soft-bottom community. J. Mar. Res. 42, 633-654.
Anderson, M.J., Underwood, A.J., 1994. Effects of substratum on the recruitment and development of an intertidal estuarine fouling assemblage. J. Exp. Mar. Biol. Ecol. 184, 217-236.

André, C., Rosenberg, R., 1991. Adult-larval interactions in the suspension feeding bivalves Cerastoderma edule and Mya arenaria. Mar. Ecol. Prog. Ser. 71, 227-234.

Austen, M.C., Buchanan, J.B., Hunt, H.G., Josefson, A.B., Kendall, M.A., 1991. Comparison of long-term trends in benthic and pelagic communities of the North Sea. J. Mar. Biol. Assoc. UK 71, 179-190.

Archambault, P., Bourget, E., 1999. Influence of shoreline configuration on spatial variation of meroplanktonic larvae, recruitment and diversity of benthic subtidal communities. J. Exp. Mar. Biol. Ecol. 238, 161-184.

Benedetti-Cecchi, L., 2000. Priority effects, taxonomic resolution, and the prediction of variable patterns of colonisation of algae in littoral rock pools. Oecologia 123, 265-274.

Bertness, M.D., Gaines, S.D., Wahle, R.A., 1996. Wind-driven settlement patterns in the acorn barnacle Semibalanus balanoides. Mar. Ecol. Prog. Ser. 137, 103-110.

Bingham, B.L., 1992. Life histories in an epifaunal community: coupling of adult and larval processes. Ecology 73, 2244-2259.

Boero, F., 1996. Episodic events: their relevance in ecology and evolution. P.S.Z.N. I: Mar. Ecol. 17, 237-250.

Boero, F., Belmonte, G., Fanelli, G., Piraino, S., Rubino, F., 1996. The continuity of living matter and the discontinuities of its constituents: do plankton and benthos really exist? Trends Ecol. Evol. 11, 177-180.

Boero, F., Bouillon, J., 1993. Zoogeography and life-cycle patterns of Mediterranean hydromedusae (Cnidaria). Biol. J. Linn. Soc. 48, 239-266.

Booth, D.J., Brosnan, D.M., 1995. The role of recruitment dynamics in rocky shore and coral reef fish communities. Adv. Ecol. Res. 26, 309-383.

Buss, L.W., 1990. Competition within and between encrusting clonal invertebrates. Trends Ecol. Evol. 5, 352-356.

Butman, C.A., 1987. Larval settlement of soft-sediment invertebrates: the spatial scales of pattern explained by active habitat selection and the emerging role of hydrodynamical processes. Oceanogr. Mar. Biol. Annu. Rev. 25, 113-165.

Caley, M.J., Carr, M.H., Hixon, M.A., Hughes, T.P., Jones, G.P., Menge, B.A., 1996. Recruitment and the local dynamics of open marine populations. Annu. Rev. Ecol. Syst. 27, 477-500.

Chesson, P.L., 1998. Recruitment limitation: a theoretical perspective. Aust. J. Ecol. 23, 234-240.

Chesson, P.L., Warner, R.R., 1981. Environmental variability promote coexistence in lottery competitive systems. Am. Nat. 117, 923-943.

Chia, F.S., Buckland-Nicks, J., Young, C.M., 1984. Locomotion of marine invertebrate larvae: a review. Can. J. Zool. 62, 1205-1222.

Coma, R., Ribes, M., Gili, J.M., Zabala, M., 2000. Seasonality in coastal benthic ecosystems. Trends Ecol. Evol. 15, 448-453.

Connell, J.H., 1985. The consequence of variation in initial settlement versus post-settlement mortality in rocky intertidal communities. J. Exp. Mar. Biol. Ecol. 93, 11-45.

Connell, J.H., Hughes, T.P., Wallace, C.C., 1997. A 30-year study of coral abundance, recruitment, and disturbance at several scales in space and time. Ecol. Monogr. 67, 461-468.

Connell, J.H., Slatyer, F., 1977. Mechanisms of successions in natural communities and their role in community stability and organization. Am. Nat. 111, 1119-1144.

Constable, A.J., 1999. Ecology of benthic macro-invertebrates in softsediment environments: a review of progress towards quantitative models and predictions. Aust. J. Ecol. 24, 452-476.

Coull, B.C., Wells, J.B.J., 1982. Refuges from fish predation: experiments with phytal meiofauna from the New Zealand rocky intertidal. Ecology 64, 1599-1609. 
Crowe, W.A., Josefson, A.B., Svane, I., 1987. Influence of adult density on recruitment into soft sediments: a short-term in situ sublittoral experiment. Mar. Ecol. Prog. Ser. 41, 61-69.

Danovaro, R., Fraschetti, S., 2002. Meiofaunal vertical zonation on hard bottoms: comparison with soft-bottom meiofauna. Mar. Ecol. Progr. Ser. 230, 159-169.

David, P., Berthou, P., Noel, P., Jarne, P., 1997. Patchy recruitment patterns in marine invertebrates: a spatial test of the density-dependent hypothesis in the bivalve Spisula ovalis. Oecologia 111, 331-340.

Davis, A.R., 1987. Variations in recruitment of the subtidal colonial ascidian Podoclavella cylindrica (Quoy and Gaimard): the role of substratum choice and early survival. J. Exp. Mar. Biol. Ecol. 106, $57-71$.

Diamond, J., 1978. Niche shifts and the rediscovery of interspecific competition. Am. Sci. 66, 322-331.

Dias, P.C., 1996. Sources and sinks in population biology. Trends Ecol. Evol. 11, 326-330.

Eggleston, D.B., Armstrong, D.A., 1995. Pre- and post-settlement determinants of estuarine Dungeness crab recruitment. Ecol. Monogr. 65, 193-216.

Ellien, C., Thiébaut, E., Barnay, A.S., Dauvin, J.C., Gentil, F., Salomon, J.C., 2000. The influence of variability in larval dispersal on the dynamics of a marine metapopulation in the eastern Channel. Oceanol. Acta 23, 423-442.

Faber, M., Proops, J.L.R., 1993. Evolution, Time, Production and the Environment. Springer-Verlag, Berlin.

Feller, R.J., Stancyk, S.E., Coull, B.C., Edwards, D.G., 1992. Recruitment of polychaetes and bivalves: long-term assessment of predictability in a soft-bottom habitat. Mar. Ecol. Prog. Ser. 87, 227-238.

Frid, C.L.J., 1989. The role of recolonization processes in benthic communities, with special reference to the interpretation of predatorinduced effects. J. Exp. Mar. Biol. Ecol. 126, 163-171.

Gage, J.D., 1994. Recruitment ecology and age structure of deep-sea invertebrates populations. In: Young, C.M., Eckelbarger, K.J. (Eds.), Reproduction, Larval Biology, and Recruitment of the Deep-sea Benthos. Columbia University Press, New York, pp. 224-242.

Gaines, S.D., Bertness, M.D., 1992. Dispersal of juveniles and variable recruitment in sessile marine species. Nature 360, 579-580.

Gaines, S.D., Lafferty, K.D., 1995. Modelling the dynamics of marine species: the importance of incorporating larval dispersal. In: McEdward, L. (Ed.), Ecology of Marine Invertebrates Larvae. CRC Press, pp. 389-412.

Gaines, S., Roughgarden, J., 1985. Larval settlement rate: a leading determinant of structure in an ecological community of the marine intertidal zone. Proc. Natl. Acad. Sci. USA 82, 3707-3711.

Gallagher, E.D., Jumars, P.A., Trueblood, D.D., 1983. Facilitation of soft-bottom benthic succession by tube builders. Ecology 64, $1200-1216$.

Giangrande, A., Geraci, S., Belmonte, G., 1994. Life-cycle and life-history diversity in marine invertebrates and the implications in community dynamics. Oceanogr. Mar. Biol. Annu. Rev. 32, 305-333.

Glémarec, M., Guillou, M., 1996. Recruitment and year-class segregation in response to abiotic and biotic factors. Oceanol. Acta 19, 409-414.

Gosselin, L.A., Qian, P.Y., 1997. Juvenile mortality in benthic marine invertebrates. Mar. Ecol. Prog. Ser. 146, 265-282.

Hall, S.J., Raffaelli, D., Thrush, S.F., 1992. Patchiness and disturbance in shallow water benthic assemblages. In: Hildrew, A., Raffaelli, D.G., Giller, P.S. (Eds.), Aquatic Ecology, Scale Pattern and Process. Blackwell Science, pp. 333-375.

Hanski, I., Simberloff, D., 1997. The metapopulation approach, its history, conceptual domain, and application to conservation. In: Hanski, I., Gilpin, M.E. (Eds.), Metapopulation Biology. Ecology, Genetics, and Evolution. Academic Press, pp. 5-26.

Highsmith, R.C., 1985. Floating and algal rafting as potential dispersal mechanisms in brooding invertebrates. Mar. Ecol. Prog. Ser. 25, 169-179.
Hines, A.H., 1986. Larval problems and perspectives in life histories of marine invertebrates. Bull. Mar. Sci. 39, 506-525.

Holm, E.R., 1990. Effects of density-dependent mortality on the relationship between recruitment and larval settlement. Mar. Ecol. Prog. Ser. 60, 141-146.

Hughes, T.P., 1990. Recruitment limitation, mortality and population regulation in open systems: a case study. Ecology 71, 12-20.

Hughes, T.P., Baird, A.H., Dinsdale, E.A., Moltschaniwskyj, N.A., Pratchett, M.S., Tanner, J.E., Willis, B.L., 1999. Patterns of recruitment and abundance of corals along the Great Barrier Reef. Nature 397, $59-63$.

Huismann, J., Weissing, F.J., 2001. Fundamental unpredictability in multispecies competition. Am. Nat. 157, 488-494.

Hunt, H.L., Scheibling, R.E., 1997. Role of early post-settlement mortality in recruitment of benthic marine invertebrates. Mar. Ecol. Prog. Ser. $155,269-301$

Hurlbut, C.J., 1991. Community recruitment: settlement and juvenile survival of seven co-occurring species of sessile marine invertebrates. Mar. Biol. 109, 507-515.

Jackson, J., 1977. Competition on marine hard substrata. The adaptative significance of solitary and colonial strategies. Am. Nat. 111, 743-767.

Jenkins, S.R., Åberg, P., Cervin, G., Coleman, R.A., Delany, J., Della Santina, P., Hawkins, S.J., LaCroix, E., Myers, A.A., Lindegarth, M., Power, A.M., Roberts, M.F., Hartnoll, R.G., 2000. Spatial and temporal variation in settlement and recruitment of the intertidal barnacle Semibalanus balanoides (L.) (Crustacea: Cirripedia) over a European scale. J. Exp. Mar. Biol. Ecol. 243, 209-225.

Kendall, M.A., Widdicombe, S., 1999. Small scale patterns in the structure of macrofaunal assemblages of shallow soft sediments. J. Exp. Mar. Biol. Ecol. 237, 127-140.

Keough, M.J., 1983. Patterns of recruitment of sessile invertebrates in two subtidal habitats. J. Exp. Mar. Biol. Ecol. 66, 213-245.

Lake, P.S., 1990. Disturbing hard and soft bottom communities: a comparison of marine and freshwater environments. Aust. J. Ecol. 15, $477-488$.

Lasker, H.R., Kim, K., Coffroth, M.A., 1998. Production, settlement, and survival of plexaurid gorgonian recruits. Mar. Ecol. Prog. Ser. 162, $111-123$.

Lewin, R., 1986. Supply-side ecology. Science 234, 25-27.

Marcus, N.H., Boero, F., 1998. The importance of benthic-pelagic coupling and the forgotten role of life-cycles in coastal aquatic systems. Limnol. Oceanogr. 43, 763-768.

McArthur, V.E., 1998. Post-settlement mortality of juvenile lagoonal cockles (Cerastoderma glaucum: Mollusca: Bivalvia. Mar. Biol. 132, $117-122$.

McKinney, F.K., McKinney, M.J., 1993. Larval behaviour and choice of settlement site: correlation with environmental distribution pattern in an erect bryozoan. Facies 29, 119-132.

Menge, B.A., 1991. Relative importance of recruitment and other causes of variation in rocky intertidal community structure. J. Exp. Mar. Biol. Ecol. 146, 69-100.

Menge, B.A., 2000. Recruitment versus post-recruitment processes as determinants of barnacle population abundance. Ecol. Monogr. 70, 265-288.

Menge, B., Farrel, T.M., 1989. Community structure and interaction webs in shallow marine hard-bottom communities: tests of an environmental stress model. Adv. Ecol. Res. 19, 189-262.

Menge, B.A., Sutherland, J.P., 1987. Community regulation: variation in disturbance, competition and predation in relation to environmental stress and recruitment. Am. Nat. 130, 730-757.

Minchinton, T.E., Scheibling, R.E., 1991. The influence of larval supply and settlement on the population structure of barnacles. Ecology 72, 1867-1879.

Morgan, S.G., 2001. The larval ecology of marine communities. In: Bertness, M.D., Gaines, S.D., Hay, M.E. (Eds.), Marine Community Ecology. Sunderland, Massachusetts. pp. 159-181. 
Noda, T., Nakao, S., 1996. Dynamics of an entire population of the subtidal snail Umbonium costatum: the importance of annual recruitment fluctuations. J. Anim. Ecol. 65, 196-204.

Norkko, A., Cummings, V.J., Thrush, S.F., Hewitt, J.E., Hume, T., 2001. Local dispersal of juvenile bivalves: implications for sandflat ecology. Mar. Ecol. Prog. Ser. 212, 131-144.

Olafsson, E.B., Peterson, C.H., Ambrose Jr, W.G., 1994. Does recruitment limitation structure populations and communities of macroinvertebrates in marine soft sediments: the relative significance of pre- and post-settlement processes. Oceanogr. Mar. Biol. Annu. Rev. $32,65-109$.

Osman, R.W., Whitlatch, R.B., 1995. The influence of resident adults on recruitment: a comparison to settlement. J. Exp. Mar. Biol. Ecol. 190, 169-198.

Osman, R.W., Whitlatch, R.B., Malatesta, R.J., 1992. Potential role of micro-predators in determining recruitment into a marine communities. Mar. Ecol. Prog. Ser. 83, 35-43.

Paine, R.T., 1974. Intertidal community structure. Experimental studies on the relationship between dominant competitor and its principal predator. Oecologia 15, 93-120.

Palmer, M.A., Allan, J.D., Butman, C.A., 1996. Dispersal as a regional process affecting the local dynamics of marine and stream benthic invertebrates. Trends Ecol. Evol. 11, 322-326.

Peterson, C.H., 1979. Predation, competition exclusion, and diversity in the soft-sediment benthic communities of estuaries and lagoons. In: Livingston, R.J. (Ed.), Ecological Processes in Coastal and Marine Systems. Plenum Press, New York, pp. 233-264.

Peterson, C.H., Summerson, H.C., 1992. Basin-scale coherence of population dynamics of an exploited marine invertebrate, the bay scallop: implications of recruitment limitation. Mar. Ecol. Prog. Ser. 90, 257-272.

Pile, A.J., Lipcius, R.N., van Montfrans, J., Orth, R.J., 1996. Densitydependent settler-recruit-juvenile relationship in blue crabs. Ecol. Monogr. 66, 277-300.

Powell, E.N., Cummings, H., Stenton Jr, R.J., Staff, G., 1984. Estimation of the size of molluscan larval settlement using the death assemblage. Estuar. Coast. Shelf Sci. 18, 367-384.

Richmond, M.D., Seed, R., 1991. A review of marine macrofouling communities with special references to animal fouling. Biofouling 3, 151-168.

Rinkevich, B., Prat, R., Goren, M., 1998. Ecological and life history characteristics of Botryllus schlosseri (Tunicata) populations inhabiting undersurface shallow-water stones. P.S.Z.N. I: Mar. Ecol. 19, 129-145.

Rodriguez, S.R., Ojeda, F.P., Inestrosa, N.C., 1993. Settlement of benthic marine invertebrates. Mar. Ecol. Prog. Ser. 97, 193-207.

Roegner, G.C., 1991. Temporal analysis of the relationship between settlers and early recruits of the oyster Crassostrea virginica (Gmelin). J. Exp. Mar. Biol. Ecol. 151, 57-69.

Roughgarden, J., Gaines, S.D., Possingham, H., 1988. Recruitment dynamics in complex life-cycles. Science 241, 1460-1466.

Roughgarden, J., Iwasa, Y., Baxter, C., 1985. Demographic theory for an open marine population with space-limited recruitment. Ecology 66, 54-67.

Sale, P.F., 1977. Maintenance of high diversity in coral reef fish communities. Am. Nat. 111, 337-359.

Sale, P.F., 1990. Recruitment of marine species: is the bandwagon rolling in the right direction? Trends Ecol. Evol. 5, 25-27.
Standing, J.D., 1976. Fouling community structure: effects of the hydroid Obelia dichotoma on larval recruitment. In: Mackie, G.O. (Ed.), Coelenterate Ecology and Behaviour. Plenum Press, New York and London, pp. 155-164.

Stoner, A.W., Glazer, R.A., Barile, P.J., 1996. Larval supply to queen conch nurseries: relationships with recruitment process and population size in Florida and Bahamas. J. Shellfish Res. 15, 407-420.

Stoner, D.S., 1990. Recruitment of a tropical ascidian: relative importance of pre-settlement versus post-settlement processes. Ecology 71, $1682-1690$.

Sutherland, J.P., 1990. Recruitment regulates demographic variations in a tropical intertidal barnacle. Ecology 71, 955-972.

Sutherland, J.P., Ortega, S., 1986. Competition conditional on recruitment and temporary escape from predators on a tropical rocky shore. J. Exp. Mar. Biol. Ecol. 95, 155-166.

Thiébaut, E., Cabioch, L., Dauvin, J.C., Retiere, C., Gentil, F., 1997. Spatio-temporal persistence of the Abra alba-Pectinaria koreni muddy-fine sand community of the eastern Bay of Seine. J. Mar. Biol. Ass. UK 77, 1165-1185.

Thiébaut, E., Lagadeuc, Y., Olivier, F., Dauvin, J.C., Retiere, C., 1998. How hydrodynamic factors affect the recruitment of marine invertebrates in a macrotidal area? The case study of Pectinaria koreni (Polychaeta) in the Bay of Seine (English Channel). Hydrobiologia 375/376, 165-176.

Thorson, G., 1950. Reproductive and larval ecology of marine bottom invertebrates. Biol. Rev. 25, 1-45.

Thrush, S.F., Hewitt, J.E., Pridmore, R.D., Cummings, W.J., 1996. Adultjuvenile interactions of infaunal bivalves: contrasting outcomes in different habitats. Mar. Ecol. Prog. Ser. 132, 83-92.

Underwood, A.J., Fairweather, P.G., 1989. Supply-side ecology and benthic marine assemblages. Trends Ecol. Evol. 4, 16-20.

Warner, R.R., Chesson, P.L., 1985. Coexistence mediated by recruitment fluctuations: a field guide to the storage effects. Am. Nat. 125, 769-787.

Watzin, M.C., 1983. The effects of meiofauna on settling macrofauna: meiofauna may structure macrofaunal communities. Oecologia 59, $163-166$

Weinberg, J.R., 1984. Interactions between functional groups in softsubstrata: do species differences matter? J. Exp. Mar. Biol. Ecol. 80, $11-28$.

Whale, R.A., Incze, L.S., 1997. Pre- and post-settlement processes in recruitment of the American lobster, Homarus americanus. J. Exp. Mar. Biol. Ecol. 217, 179-207.

Wilson, W.H., 1994. Dispersal of soft-bottom benthos: migration through the water column or through the sediment? In: Wilson, W.H., Stricker, S.A., Shinn, G.L. (Eds.), Reproduction and Development of Marine Invertebrates. The Johns Hopkins University Press, pp. 302-312.

Woodin, S.A., 1976. Adult-larval interactions in dense infaunal assemblages: patterns of abundance. J. Mar. Res. 34, 25-41.

Young, E.F., Bigg, G.R., Grant, A., Walker, P., Brown, J., 1998. A modelling study of environmental influences on bivalve settlement in the Wash. England. Mar. Ecol. Prog. Ser. 172, 197-214.

Zobrist, E.C., Coull, B.C., 1992. Meiobenthic interactions with macrobenthic larvae and juveniles: an experimental assessment of the meiofaunal bottleneck. Mar. Ecol. Prog. Ser. 88, 1-8. 